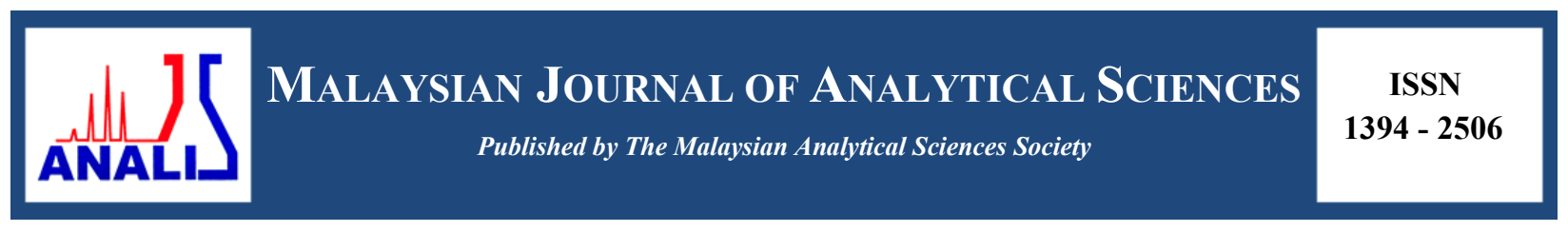

\title{
THE INFLUENCE OF CARBONIZATION TEMPERATURE ON THE DEVELOPMENT OF CARBON MEMBRANE WITH SUPERIOR $\mathrm{CO}_{2} / \mathrm{CH}_{4}$ SEPARATION PERFORMANCE
}

\author{
(Pengaruh Suhu Karbonisasi Kepada Pembangunan Membran Karbon Dengan Kesan Pemisahan \\ Gas $\mathrm{CO}_{2} / \mathrm{CH}_{4}$ Yang Cemerlang)
}

\author{
Norazlianie Sazali $^{1,2}$,Wan Norharyati Wan Salleh ${ }^{1,2}$, Mohamad Azuwa Mohamed ${ }^{1,2}$, Nor Hafiza Ismail ${ }^{1,2}$, \\ Norafiqah Rosman ${ }^{1,2}$, Farhana Aziz ${ }^{1,2}$, Ahmad Fauzi Ismail ${ }^{1,2}$ \\ ${ }^{1}$ Advanced Membrane Technology Research Centre (AMTEC) \\ ${ }^{2}$ Faculty of Chemical and Energy Engineering (FCEE) \\ Universiti Teknologi Malaysia, 81310 Skudai, Johor Darul Takzim, Malaysia. \\ *Corresponding author: hayati@petroleum.utm.my
}

Received: 26 August 2016; Accepted: 8 January 2017

\begin{abstract}
In this study, P84-based carbon tubular membranes were fabricated and characterized in terms of their structural morphology and gas permeation properties, by using Scanning Electron Microscopy (SEM) and pure gas permeation system, respectively. The polymer tubular membranes were then carbonized under nitrogen atmosphere at different carbonization temperatures of 600 , 700,800 and $900{ }^{\circ} \mathrm{C}$, with heating rate of $3^{\circ} \mathrm{C} / \mathrm{min}$ and thermal soak time of 30 minutes. The manipulation of carbonization temperatures was required to see if it could enhance the permeation properties as desired. Pure gas permeation tests were performed using $\mathrm{CO}_{2}$ and $\mathrm{CH}_{4}$ gases. The $\mathrm{CO}_{2} / \mathrm{CH}_{4}$ selectivity was found increasing as the carbonization temperature was increased from 600 to $800{ }^{\circ} \mathrm{C}$. The carbon membrane carbonized at $800^{\circ} \mathrm{C}$ showed the most promising result for $\mathrm{CO}_{2} / \mathrm{CH}_{4}$ selectivity, rendering 69.48 and $\mathrm{CO}_{2}$ permeance of $206.1 \mathrm{GPU}$.
\end{abstract}

Keywords: carbonization temperature, tubular support, P84 copolyimide, carbon membrane, gas separation

Abstrak

Dalam kajian ini, membran tiub karbon berasaskan P84 telah direka dan dicirikan dari segi morfologi dan penyerapan gas dengan menggunakan mikroskopi elektoron pengimbasan (SEM), dan sistem penyerapan gas tulen. Membran polimer tiub kemudian dikarbonisasi dalam kawalan gas nitrogen pada suhu karbonisasi berbeza iaitu $600,700,800$ dan $900{ }^{\circ} \mathrm{C}$ dengan kadar pemanasan $3{ }^{\circ} \mathrm{C} / \mathrm{min}$ dan kawalan haba selama 30 minit. Pengubahsuaian syarat karbonisasi diperlukan untuk mempertingkatkan ciri - ciri penyerapan gas. Ujian penyerapan gas tulen telah dilakukan dengan menggunakan gas $\mathrm{CO}_{2}$ dan gas $\mathrm{CH}_{4}$. $\mathrm{Keterpilihan}$ gas $\mathrm{CO}_{2} / \mathrm{CH}_{4}$ telah meningkat apabila suhu karbonisasi meningkat daripada $600 \mathrm{ke} 800^{\circ} \mathrm{C}$. Daripada kajian ini, membran karbon yang dikarbonisasi pada suhu $800{ }^{\circ} \mathrm{C}$ menunjukkan bacaan yang paling tinggi dengan nilai keterpilihan $\mathrm{CO}_{2} / \mathrm{CH}_{4}$ sebanyak 69.48 dan nilai kebolehtelapan $\mathrm{CO}_{2}$ ialah 206.1 GPU.

Kata kunci: suhu karbonisasi, sokongan tubul, P84 kopolimid, membran karbon, pemisahan gas

\section{Introduction}

Membrane technology has gained interest as fluids separation media. Membrane is semi permeable barrier that allows only specific molecules to pass through, while discriminating others. Since there is no occurrence of phase 
change during the separation [1], membranes technology offers minimal energy requirement [2]. Moreover, the membrane technology incorporating an efficient and straightforward separation approach with no moving parts makes it as preferable process. The membrane technology has shown a great industrial potential in seawater desalination, water filtration, wastewater treatment, dialysis and gas separation. Since the past decades, the depletion of natural gas quality, where the presence of impurities is prominent, has encouraged researches on membrane technology to focus on natural gas purification [3,4]. There are several well-established processes such as adsorption, chemical absorption and cryogenic distillation which have been implemented in the purification process. These conventional processes, however, are known to suffer from high energy requirement, toxic refrigerant, unit corrosion, expensive maintenance and high operation cost. Membrane for gas separation offers a lot of advantages including space efficiency, requiring no complicated integration into the power plant, no regeneration, and chemical are not needed [5].

However, there is a trade-off suffered by polymeric membrane; which highly permeable membranes commonly accompanied by poor gas pair selectivity and vice versa $[6,7]$. Since then, researches has highlights numerous strategies to overcome the limitation. Among them, new class of membrane known as carbon membrane was discovered. Carbon membrane is resulted from carbonized formed of polymeric precursor. During carbonization, polymeric precursor began to decompose, causing the functional group presence to breakage and form amorphous material. The resulted amorphous material having bimodal pore distribution having better thermal stability, chemically resistant towards various concentrations of acid, hot organic solvent and alkaline solution compared to their polymeric counterpart [8-9]. The gas separation performance of carbon membrane has been highlighted over the years. Owing to their bimodal pore distribution, carbon membrane performed well above the Robeson Upperbound. However, due to the fragility of carbon membrane structure, good handling is needed to avoid structural collapse [10]. To overcome the limitation, fabricating carbon membrane on ceramic substrate is among preferable approach [11]. In this study, supported carbon membrane was prepared via dip-coating method due to its straightforwardness approach and cost-effective $[12,13]$.

Since development of tubular supported carbon membrane is a relatively new approach, it is important to identify the most ideal carbonization temperature that could result in high performance carbon membrane. Therefore, this study aims to develop tubular supported carbon membrane for $\mathrm{CO}_{2} / \mathrm{CH}_{4}$ separation using different carbonization temperatures.

\section{Materials and Methods}

A commercially available polyimide-type polymer was chosen as a precursor, which is a thermally stable copolyimide BTDA-TDI/MDI (P84), procured from Sigma Aldrich (CAS\#: 58698-66-1). The measured density of P84 was about $1.31 \mathrm{~g} / \mathrm{cm}^{3}$ with glass transition temperature $\left(\mathrm{T}_{\mathrm{g}}\right)$ of $315^{\circ} \mathrm{C}[14]$. N-Methyl-2-Pyrrolidone (NMP) was used as solvent; which is a strong, aprotic solvent with high solvency and low volatility, purchased from Merck (Germany). Porous tubular ceramic was purchased from Shanghai Gongtao Ceramics Co. Ltd. The dimension of the porous tubular ceramic was about $8 \mathrm{~cm}$ in length, $13 \mathrm{~mm}$ in outer diameter and $10 \mathrm{~mm}$ in inner diameter. The porosity of the support was $40-50 \%$ with an average pore size of $0.2 \mu \mathrm{m}$.

To begin, P84 was dissolved in NMP, stirred using mechanical stirrer and sonicated to remove trapped bubbles from the solution. The tubular support was immersed into the polymeric solution for 15 minutes and the process was repeated three times. The supported membrane was dried at temperature of $80{ }^{\circ} \mathrm{C}$ for 24 hours, followed by immersion in methanol for 2 hours. The sample was then placed in oven at temperature of $100{ }^{\circ} \mathrm{C}$ for 2 hours to remove the methanol prior to carbonization. Subsequently, the supported membrane was placed at the center of the Carbolite horizontal tubular furnace to undergo carbonization process. Heat treatment was performed at $300{ }^{\circ} \mathrm{C}$ for 30 minutes, followed by carbonization at temperatures of $600{ }^{\circ} \mathrm{C}, 700{ }^{\circ} \mathrm{C}, 800{ }^{\circ} \mathrm{C}$ and $900{ }^{\circ} \mathrm{C}$, with heating rate of 3 ${ }^{\circ} \mathrm{C} / \mathrm{min}$ under nitrogen gas $(200 \mathrm{~mL} / \mathrm{min})$ as illustrated in Figure 1 . The nomenclature of the resultant carbon tubular membrane was given in the form of CM-Carbonization Temperature and the resultant carbon membranes was given in the form (CM-Carbonization Temperature); denoted as CM-600, CM-700, CM-800, CM-900. All samples were cooled naturally at room temperature under air atmosphere after completing each heating cycle. 


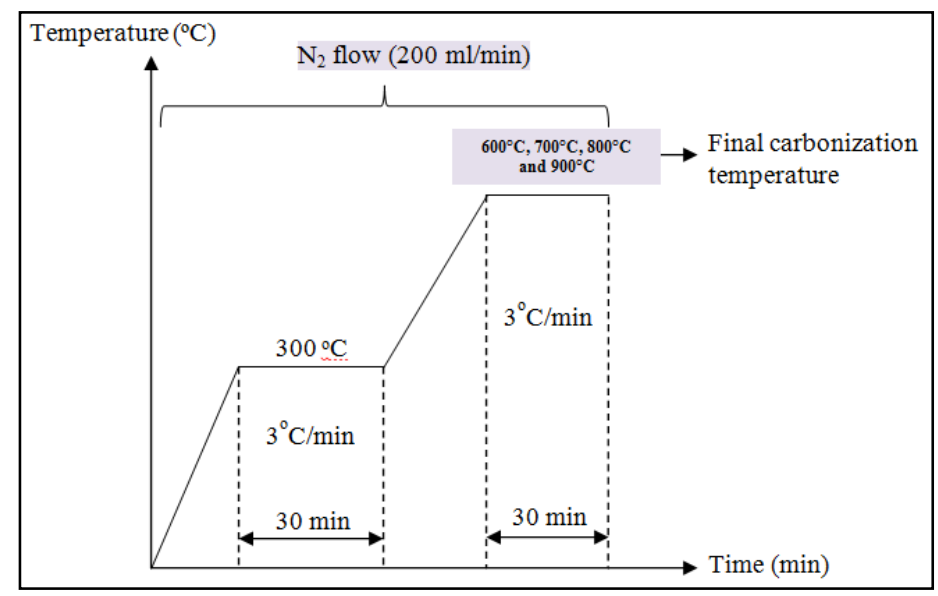

Figure 1. Heat treatment profile

The morphological structures of the P84-based membranes were viewed via scanning electron microscopy (SEM) model JEOL JSM-5610LV. In this study, free-standing carbon membrane in the form of flat sheet (without tubular support) was prepared for characterization purposes. The membrane was fabricated under the same condition as supported carbon membrane. A small piece of the tested membranes was cut and conditioned in liquid nitrogen to prepare an unreformed structure, which was then mounted on sample stubs. The sample was then coated with gold by sputter coating under vacuum. The performance of the carbon membrane was indicated by the gas permeance and gas selectivity. The carbon tubular membranes were tested using in-house gas permeation system. The system consists of flexible hose, permeation cell, valve, pressure regulator and soap bubble meter, which was fabricated to measure the pure gas permeation rate for tubular supported membranes. The $8 \mathrm{~cm}$ carbon tubular membrane was placed inside tubular stainless steel module, which was $14 \mathrm{~cm}$ in length. The membrane was fitted with rubber Orings to allow the membrane to be housed in the module without leakages.

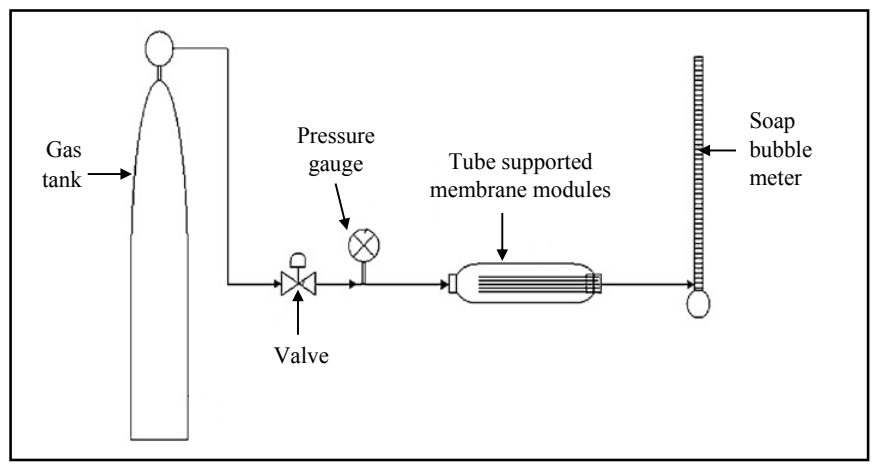

Figure 2. Gas permeation system [15]

Figure 2 shows the gas permeation system reported by a previous study [9]. Pure $\mathrm{CO}_{2}(0.33 \mathrm{~nm})$ and $\mathrm{CH}_{4}(0.38 \mathrm{~nm})$ gases were fed separately into the module at a trans membrane pressure of 8 bars. The permeance, $P / l(\mathrm{GPU})$ and selectivity, $\alpha$ of the membranes were calculated using the following equations: 
Permeance, $P$ :

$$
(P / l)_{i}=\frac{Q_{i}}{\Delta p \cdot A}=\frac{Q}{\pi D l \Delta P}
$$

Selectivity, $\alpha$ :

$$
\alpha_{A / B}=\frac{P_{A}}{P_{B}}=\frac{(P / l)_{A}}{(P / l)_{B}}
$$

where $P / l$ is the permeance of the membrane, $Q i$ is the volumetric flow rate of gas $i$ at standard temperature and pressure $\left(\mathrm{cm}^{3}(\mathrm{STP} / \mathrm{s}), p\right.$ is the pressure difference between the feed side and the permeation side of the membrane $(\mathrm{cmHg}), A$ is the membrane surface area $\left(\mathrm{cm}^{2}\right), D$ is an outer diameter of the membrane $(\mathrm{cm})$, and $l$ is an effective length of the membrane $(\mathrm{cm})$.

The volumetric flow rate of gas permeate was measured by using the soap bubble flow meter. Similar gas permeation system had also been used in the previous study [13]. The feed pressure of 8 bars was applied throughout the experiment. This permeation test was repeated for at least three membrane samples.

\section{Results and Discussion}

Scanning Electron Microscopy (SEM) was used to characterize the morphological structure of P84-based polymeric and carbon membranes prepared under different carbonization temperature. Figure 3(a) shows the cross section microphotographs of the P84-based polymeric membrane, while Figure 3(b) to 3(e) show the cross section microphotographs of P84-based carbon membranes prepared at $600,700,800$ and $900{ }^{\circ} \mathrm{C}$. It was observed that all P84 membranes tested under different carbonization temperature had porous structure. Compared between P84based polymeric membrane and P84-based carbon membrane under different carbonization temperature, it was clearly seen that P84-based carbon membranes with high carbonization temperature had higher density, compactness structure and less thickness, as shown in Figures 3(b) to 3(e), than P84-based polymeric membranes, as shown in Figure 3(a). It was found that the formed polymer chains had increased the packing density of the membranes, and some of the pores had become narrow due to the densification of carbon structure. Similar findings had also been reported elsewhere [16]. As the final carbonization temperature was increased, the gas passed through the membrane structure according to their kinetic diameter. Thus, the increment of carbonization final temperature produced a carbon membrane with a higher permeability and selectivity.

As can be seen in Figures 3(b) to 3(e), the structure of the prepared membrane experienced increasing density when temperature was increased from CM-600 to CM-800. On the other hand, the morphological structure for CM 900 resulted in low packing density, as higher temperatures caused the pores to shrink and finally disappeared. At 700 to $800{ }^{\circ} \mathrm{C}$, the pores started to enlarge up; however when the temperature reached around $1000{ }^{\circ} \mathrm{C}$, the pores of the carbonized material were mainly closed [17].

The permeance and selectivity of the membranes were then measured using gas permeation test apparatus at room temperature (Table 1). From the gas permeation test, the performance of the P84-based tube supported carbon membrane was characterized by two important factors, which are permeance and selectivity. As shown by the gas permeation test results, the carbon membranes had presented an excellent performance compared to the polymeric membranes. In addition, the increment in smaller molecule permeance was more prominent compared to larger molecules, resulting in higher gas pair selectivity, according to the increment of carbonization temperature. Carbon membranes contain constrictions in its structure which are closer to molecular dimensions of gas molecules compared to polymeric membranes. The pore system generally consisted of extensive openings with narrow constrictions. The separation was caused by the passage of smaller gas molecules through the pores, while the larger gas molecules were blocked, as well as due to the transport mechanism. Thus, it exhibited high selectivity for the smaller gas molecules, which were $\mathrm{CO}_{2}$. These findings are in agreement with the work done by Ismail and David [18]. For both precursor and carbon membranes, the best performance of the membranes was obtained at the pressure of 8 bars. This result could be endorsed to the combination of low porosity and the kinetic diameter of the 
gases, which could result to the pore blocking and resistance of gas transport at higher feed pressure. Similar results were also reported by Hosseini and Chung [19].
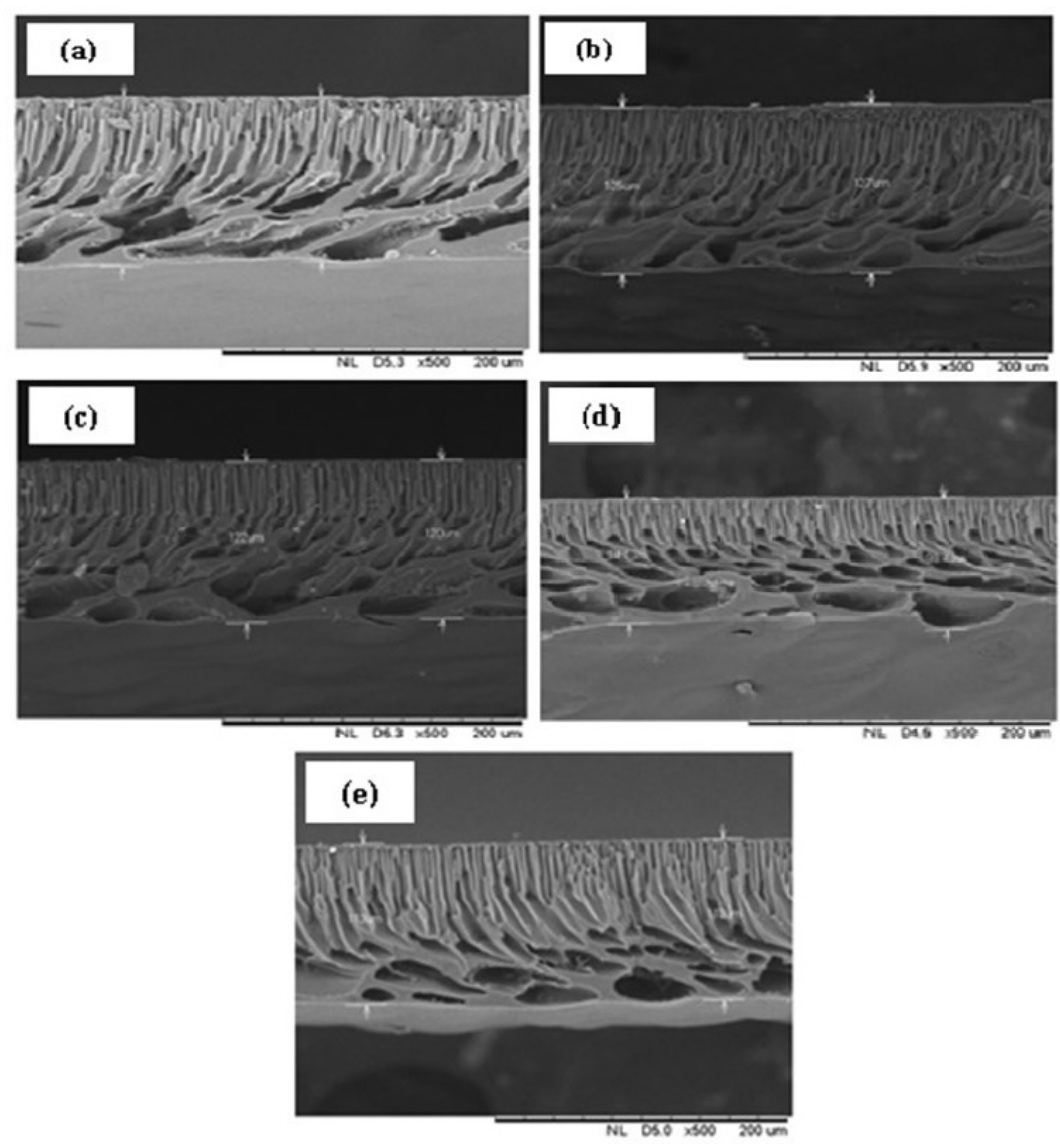

Figure 3. SEM images for (a) P84 Polymeric, (b) CM-600, (c) CM-700, (d) CM-800, and (e) CM-900

In general, low carbonization temperature would produce membrane with poor performances due to poor structural arrangements. On the other hand, at excessive high carbonization temperature, the structural of the carbon membrane would collapse and result in highly dense membrane. Accordingly, the permeability of two pure gases with different molecular sizes; $\mathrm{CO}_{2}(3.30 \AA)$, and $\mathrm{CH}_{4}(3.80 \AA)$, through the resulting carbon membranes were measured. The gas permeance of the prepared carbon membranes was found following the order of $\mathrm{CO}_{2}>\mathrm{CH}_{4}$, according to their kinetic diameters. Consequently, the gas permeance was hindered while possessing poor gas pair selectivity. In addition, the micropores within the carbon membrane allowed smaller molecules (kinetic diameter of $\mathrm{CO}_{2}$ is $3.3 \AA$ ) to permeate easily across the membrane, while discriminating larger molecule (kinetic diameter of $\mathrm{CH}_{4}$ is $3.8 \AA$ ), or better known as molecular sieving effect. The molecular sieving effect, commonly reported as separation mechanism in carbon membrane, resulted from the breakage of benzene ring and other functional group, and created bimodal rigid pore distribution. Hence, the resulting membrane showed high $\mathrm{CO}_{2}$ permeance and $\mathrm{CO}_{2} /$ $\mathrm{CH}_{4}$ selectivity. The permeability of $\mathrm{CO}_{2}$, and $\mathrm{CH}_{4}$ gases increased due to increase of carbonization temperature from 600 to $800{ }^{\circ} \mathrm{C}$. 
Table 2. Gas Permeance and Selectivity of polymeric and carbon membranes.

\begin{tabular}{|c|c|c|c|}
\hline \multirow[t]{2}{*}{ Sample } & \multicolumn{2}{|c|}{ Permeance (GPU) } & \multirow{2}{*}{$\begin{array}{c}\text { Selectivity } \\
\alpha_{\mathrm{CO} 2 / \mathrm{CH} 4}\end{array}$} \\
\hline & $\mathrm{CO}_{2}$ & $\mathrm{CH}_{4}$ & \\
\hline P84 Polymeric & 1.21 & 0.46 & 2.63 \\
\hline CM-600 & 7.42 & 1.12 & 6.63 \\
\hline CM-700 & 122.81 & 2.86 & 42.94 \\
\hline CM-800 & 205.67 & 2.96 & 69.48 \\
\hline CM-900 & 175.39 & 2.90 & 60.48 \\
\hline
\end{tabular}

However, the gas permeance decreased when $900{ }^{\circ} \mathrm{C}$ of carbonization temperature was applied. This indicates that pores and carbon structure of the carbon membrane became rigid and compact; and some of the pores might change into closed pores during the carbonization. This phenomenon is often related to structure compaction and entanglement of polymer chain when polymer composition exceeds the ideal temperature. Consequently, poor structural arrangements induced higher mass transport resistance and hindered the permeation of all tested gases. In addition, significant reduction of $\mathrm{CO}_{2}$ permeance compared to $\mathrm{CH}_{4}$ further suggested severe structural arrangement for at macroscopic level at $900{ }^{\circ} \mathrm{C}$ carbonization temperature, leading to lesser $\mathrm{CO}_{2} / \mathrm{CH}_{4}$ selectivity.

Further carbonization temperature caused the pores to shrink and finally disappear. This pattern is in agreement with the fact that at high temperature, carbonized membranes will possess a microporous structure that is capable to recognize different kinetic diameter of gases, which then will increase the selectivity. Similar findings were also reported by Salleh and Ismail [16]. The increasing trend suggested that the micropores formation and the carbon structure of the carbon membrane became rigid and compact; and some of the pores might change into closed pores during the carbonization process. In general, high carbonization temperature will induce higher porosity. Polyimides are known to exhibit high permselectivity for various gas pairs; especially for $\mathrm{CO}_{2} / \mathrm{CH}_{4}$, and high chemical resistance, thermal stability and mechanical strength. Many researchers reported that P84 polyimide as one of the best materials for membrane-based $\mathrm{CO}_{2} / \mathrm{CH}_{4}$ separation, due to its attractive combination of gas permselectivity and permeability [20].

\section{Conclusion}

The gas permeation properties of prepared tubular supported carbon membrane are highly dependent on carbonization temperatures. Results in this study revealed that the ideal $\mathrm{CO}_{2} / \mathrm{CH}_{4}$ selectivity of 69.48 with $\mathrm{CO}_{2}$ permeance of $206.10 \mathrm{GPU}$ can be obtained by using carbon membranes at temperature of $800{ }^{\circ} \mathrm{C}$. The study also shows that tubular supports possess higher membrane area per unit module volume, which results in high permeance.

\section{Acknowledgement}

The authors gratefully acknowledge the financial support from Ministry of Higher Education and Universiti Teknologi Malaysia (UTM) under Higher Institution Centre of Excellence Scheme (Project Number: R.J090301.7846.4J188) and research University Grant Scheme (Project Number: Q.J130000.25546.12H76; Q.J130000.2642.10J79). The authors would also like to acknowledge technical and management support from Research Management Centre (RMC), Universiti Teknologi Malaysia

\section{References}

1. Favre, E. (2010). Polymeric membranes for gas separation, in comprehensive membrane science and engineering, E. Drioli and L. Giorno (Editors). Elsevier: Oxford: pp. 155 - 212.

2. Lie, J. A. and Hägg, M.-B. (2006). Carbon membranes from cellulose: Synthesis, performance and regeneration. Journal of Membrane Science, 284: 79 - 86.

3. Adewole, J. K., Ahmad, A. L., Ismail, S. and Leo, C. P. (2013). Current challenges in membrane separation of $\mathrm{CO}_{2}$ from natural gas: A review. International Journal of Greenhouse Gas Control, 17: 46 - 65. 
4. Md Nordin, N. A. H., Racha, S. M., Matsuura, T., Misdan, N., Sani, N. A. A., Ismail, A. F. and Mustafa, A. (2015). Facile modification of ZIF-8 mixed matrix membrane for $\mathrm{CO}_{2} / \mathrm{CH}_{4}$ separation: Synthesis and preparation. RSC Advances, 5: 43110 - 43120.

5. Salleh, W. N. W., Ismail, A. F., Matsuura, T. and Abdullah, M. S. (2011). Precursor selection and process conditions in the preparation of carbon membrane for gas separation: A review. Separation \& Purification Reviews, 40: 261 - 311.

6. Robeson, L. M. (1991). Correlation of separation factor versus permeability for polymeric membranes. Journal of Membrane Science, 62: 165 - 185.

7. Reuse, E. (2016). Polymeric membranes for gas separation, in reference module in materials science and materials engineering. Elsevier.

8. Gilron, J. and Soffer, A. (2002). Knudsen diffusion in microporous carbon membranes with molecular sieving character. Journal of Membrane Science, 209: 339 - 352.

9. Sazali, N., Salleh, W. N. W., Nordin, M., Hadi, N. A., Harun, Z. and Ismail, A. F. (2015). Matrimid-based carbon tubular membranes: The effect of the polymer composition. Journal of Applied Polymer Science, 132: 42394 - 42400.

10. Saufi, S. M. and Ismail, A. F. (2004). Fabrication of carbon membranes for gas separation - A review. Carbon, 42: $241-259$.

11. Briceño, K., Montané, D., Garcia-Valls, R., Iulianelli, A. and Basile, A. (2012). Fabrication variables affecting the structure and properties of supported carbon molecular sieve membranes for hydrogen separation. Journal of Membrane Science, 415 - 416: 288 - 297.

12. Kargari, A., Shamsabadi, A. A. and Babaheidari, M. B. (2014). Influence of coating conditions on the $\mathrm{H}_{2}$ separation performance from $\mathrm{H}_{2} / \mathrm{CH}_{4}$ gas mixtures by the PDMS/PEI composite membrane. International Journal of Hydrogen Energy, 39: 6588 - 6597.

13. Sazali, N., Salleh, W. N. W., Nordin, N. A. H. M. and Ismail, A. F. (2015) Matrimid-based carbon tubular membrane: Effect of carbonization environment. Journal of Industrial and Engineering Chemistry, 32: 167 . 171.

14. Lua, A. C. and Shen, Y. (2013). Preparation and characterization of asymmetric membranes based on nonsolvent/NMP/P84 for gas separation. Journal of Membrane Science, 429: 155 - 167.

15. Basu, A., Akhtar, J., Rahman, M. H. and Islam, M. R. (2004). A review of separation of gases using membrane systems. Petroleum Science and Technology, 22:1343 - 1368.

16. Salleh, W. N. W. and Ismail, A. F. (2012). Fabrication and characterization of PEI/PVP-based carbon hollow fiber membranes for $\mathrm{CO}_{2} / \mathrm{CH}_{4}$ and $\mathrm{CO}_{2} / \mathrm{N}_{2}$ separation. AIChE Journal, 58: 3167 - 3175 .

17. Fuertes, A. B., Nevskaia, D. M. and Centeno, T. A. (1999). Carbon composite membranes from Matrimid® and Kapton ${ }^{\circledR}$ polyimides for gas separation. Microporous and Mesoporous Materials, 33: 115 - 125.

18. Ismail, A. F. and David, L. I. B. (2001). A review on the latest development of carbon membranes for gas separation. Journal of Membrane Science, 193: 1 - 18.

19. Hosseini, S. S., Peng, N., and Chung, T. S. (2010). Gas separation membranes developed through integration of polymer blending and dual-layer hollow fiber spinning process for hydrogen and natural gas enrichments. Journal of Membrane Science, 349: 156 - 166.

20. Barsema, J. N., Klijnstra, S. D., Balster, J. H., van der Vegt, N. F., Koops, G. H. and Wessling, M. (2004). Intermediate polymer to carbon gas separation membranes based on Matrimid PI. Journal of Membrane Science, 238: 93 - 102. 